\title{
PERSONNEL SELECTION USING GROUP FUZZY AHP AND SAW METHODS
}

\author{
Ali Reza AFSHARI ${ }^{1}$, Milan NIKOLIĆ ${ }^{2}$, Zahra AKBARI ${ }^{3}$ \\ ${ }^{1}$ Department of Industrial Engineering, Shirvan Branch, Islamic Azad University, Shirvan, Iran \\ E-mail: afshari@mshdiau.ac.ir \\ ${ }^{2}$ University of Novi Sad, Technical faculty ”Mihajlo Pupin” Zrenjanin, 23000 Zrenjanin, Đure Đakovića bb, \\ Republic of Serbia \\ ${ }^{3}$ University of Applied Science and Technology, Tehran, Iran
}

Paper received: 10.04.2017.; Paper accepted: 22.05.2017.

\begin{abstract}
Personnel evaluation and selection is a very important activity for the enterprises. Different job needs different ability and the requirement of criteria which can measure ability is different. It needs a suitable and flexible method to evaluate the performance of each candidate according to different requirements of different jobs in relation to each criterion. Analytic Hierarchy Process (AHP) is one of Multi Criteria decision making methods derived from paired comparisons. Simple Additive Weighting (SAW) is most frequently used multi attribute decision technique. The method is based on the weighted average. It successfully models the ambiguity and imprecision associated with the pair wise comparison process and reduces the personal biasness. This study tries to analyze the Analytic Hierarchy Process in order to make the recruitment process more reasonable, based on the fuzzy multiple criteria decision making model to achieve the goal of personnel selection. Finally, an example is implemented to demonstrate the practicability of the proposed method.
\end{abstract}

Keywords: Fuzzy AHP, SAW Method, Personnel selection, Fuzzy decision making.

\section{PERSONNEL SELECTION BACKGROUND}

As in many decision problems, personnel selection problem is very complex in real life. Multi criteria decision making (MCDM) has been widely used to deal with decision-making problems involving multiple criteria selection of alternatives. To manage this personnel selection problem, various methods have been proposed to decide on the selection of human resources. Liang and Wang (1992) presented a model by using concepts of fuzzy set theory assess personnel fitness and job vacation. On the other hand, fuzzy sets decision theory suggested by Alliger, Feinzig, and Janak (1993) for the personnel selection problem. Liang and Wang (1994) developed a fuzzy MCDM methodology to find the final ranking values for candidates in personnel selection problem. Yaakob and Kawata (1999) used fuzzy methodology for solving workers' placement problem. Lovrich (2000) used fuzzy linguistic model for personnel selection. Capaldo and Zollo (2001) presented a model based on a case study in FIAT Research Centre (CRF) that is a major Italian company. Butkiewicz (2002) used fuzzy numbers for staff selection. Chen and Cheng (2005) combined Group decision support system (GDSS) with MCDM in fuzzy environment to solve the personnel selection problem. Golec and Kahya (2007) developed a hierarchical structure and used a fuzzy model for personnel selection. Zavadskas, Turskis, Tamošaitiene and Marina (2008) applied complex proportional assessment of alternatives with grey relations to select construction project manager. Liao and Chang (2009b) used ANP to choose public relations personnel for Taiwanese hospitals. Liao and Chang (2009a) applied ANP to select televised sportscasters for Olympic Games. Dağdeviren (2010) employed ANP and modified TOPSIS to select personnel. Dursun and Karsak (2010) used the principles of fuzzy information fusion, 2-tuple linguistic representation model, and 
TOPSIS to select personnel. Kelemenis and Askounis (2010) proposed a new approach on the basis of fuzzy TOPSIS to select information technology (IT) professionals. Lin (2010) combined ANP and fuzzy data envelopment analysis (DEA) to select personnel. Boran, Genç and Akay (2011) applied Intuitionistic fuzzy TOPSIS to select a sales manager in a manufacturing company. Keršulienė and Turskis (2011) integrated the principles of fusion of fuzzy information, additive ratio assessment method with fuzzy numbers and step-wise weight assessment ratio analysis technique to select architect. Zhang and Liu (2011) proposed an intuitionistic fuzzy multi-criteria decision making method with grey relational analysis (GRA) to select system analysis engineer. Baležentis, Baležentis and Brauers (2012) modified fuzzy multi objective optimization by ratio analysis plus the full multiplicative form (MULTIMOORA) for personnel selection. Dadelo, Turskis, Zavadskas and Dadeliene (2012) presented The Use of a Hybrid MCDM Model for Public Relations Personnel Selection 391 model for personnel selection based on expert evaluation method and ARAS method. El-Santawy and ElDean (2012) employ VIKOR to rank the candidates. Zolfani, Rezaeiniya, Aghdaie and Zavadskas (2012) used AHP and TOPSIS with grey relations to select a new drummer for a rock band. Kabak, Burmaoğlu and Kazançoğlu (2012) combine fuzzy ANP, fuzzy TOPSIS and fuzzy ELECTRE to select sniper. Rouyendegh and Erkan (2012) utilized fuzzy AHP to select most suitable academic staff. Afshari, Yusuff and Derayatifar (2013) propose a new linguistic extension of fuzzy measure and fuzzy integral for personnel selection. Dadelo, Turskis, Zavadskas and Dadeliene (2013) applied wisdom-of-crowds principle, TOPSIS, and SAW to select security guard. Hadad, Keren and Laslo (2013) proposed decision-making support system module to select project managers. Kabak (2013) applied fuzzy decision-making trial and evaluation laboratory DEMATEL-ANP model to select snipers. Rouyendegh and Erkan (2013) used fuzzy ELECTRE to select academic staff. Yu, Zhang and $\mathrm{Xu}$ (2013) explored aggregation methods for preferential hesitant fuzzy elements and their application on representative personnel evaluation. Ballı and Korukoğlu (2014) used fuzzy AHP and TOPSIS to select skilful basketball players. Dadelo et al. (2013) proposed 2 optimizing algorithms to select security guards. Keršulienė and Turskis (2014) integrated the principles of fusion of fuzzy information, ARAS method with fuzzy numbers, fuzzy weighted- product model and AHP to select a chief accounting officer. Md Saad, Ahmad, Abu and Jusoh (2014) presented a novel approach of handling personnel selection process by using the Hamming distance method.

In the current study personnel selection problem is considered as a multi criteria group decision making problem. In this paper, we proposed a personnel selection system based on Fuzzy Analytic Hierarchy Process (FAHP) and SAW method. The FAHP is applied to evaluate the best adequate personnel dealing with the rating of both qualitative and quantitative criteria.

\section{MATERIAL AND METHODS}

In real-world cases, most problems have more than one decision criterion. As the result, MCDM methods have been developed to solve complex problems. The aim in MCDM is to determine overall preferences among alternatives.

\section{Analytic Hierarchy Process (AHP)}

The analytic hierarchy process (AHP) is a widely used multi criteria decision making method introduced by Saaty (1980). It resolves decisionmaking problems by structuring each problem into a hierarchy with different levels of criteria. In other words, AHP structures a decision problem into a hierarchy and evaluates multi-criteria tangible and intangible factors systematically. AHP also has been applied in numerous fields including many personnel selection decisions, (Vaidya \& Kumar, 2006). The purpose of AHP is to capture the expert's knowledge; the conventional AHP still cannot reflect the human thinking style. Therefore, fuzzy AHP, a fuzzy extension of AHP, was developed to solve the hierarchical fuzzy problems. In the fuzzy-AHP procedure, the pair wise comparisons in the judgment matrix are fuzzy numbers that are modified by the designer's emphasis.

\section{Fuzzy Sets Theory}

Zadeh (1965), introduced the fuzzy set theory which was oriented to the rationality of uncertainty due to imprecision or vagueness. A major contribution of fuzzy set theory is its capability of representing vague data. The theory also allows mathematical operators and programming to apply to the fuzzy domain. A fuzzy set is a class of objects with a continuum of grades of membership. 
Such a set is characterized by a membership (characteristic) function, which assigns to each object a grade of membership ranging between zero and one. A tilde “ $\sim$ " will be placed above a symbol if the symbol represents a fuzzy set. A triangular fuzzy number (TFN), $\tilde{M}$ is shown in Figure 1.

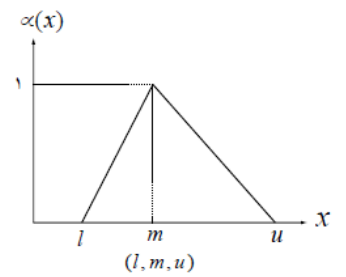

Figure 1: A triangular fuzzy number

A TFN is denoted simply as $\left(\frac{m_{1}}{m_{2}}, \frac{m_{2}}{m_{3}}\right)$ or $\left(m_{1}, m_{2}, m_{3}\right)$. The parameters $m_{1}, m_{2}$ and $m_{3}$ respectively denote the smallest possible value, the most promising value, and the largest possible value that describes a fuzzy event, (Kahraman, Cebeci, \& Ulukan, 2003).

\section{Linguistic variables}

According to Zadeh (1975), it is very difficult for conventional quantification to express reasonably those situations that are overtly complex or hard to define; so the notion of a linguistic variable is necessary in such situation. A linguistic variable is a variable whose values are words or sentences in a natural or artificial language. Here, we use this kind of expression to compare two criteria by nine basic linguistic terms from one to nine respectively, as 'Equal Importance', 'Weak or Slight', 'Moderate Importance', 'Moderate Plus', 'Strong Importance', 'Strong Plus', 'Very Strong', 'Very, very Strong' and 'Extreme Importance' with respect to a fuzzy nine level scale (see Table $1)$.

\section{Simple Additive Weighting (SAW)}

Simple Additive Weighting which is also known as weighted linear combination or scoring methods is a simple and most often used multi attribute decision technique. The method is based on the weighted average. An evaluation score is calculated for each alternative by multiplying the scaled value given to the alternative of that attribute with the weights of relative importance, directly assigned by decision maker and followed by summing of the products for all criteria. The advantage of this method is that it is a proportional linear transformation of the raw data which means that the relative order of magnitude of the standardized scores remains equal.

Table 1: Membership function of linguistic scale
\begin{tabular}{|c|c|}
\hline Intensity of Importance & Definition \\
\hline$(1,1,1)$ & Equal Importance \\
\hline$(1,2,3)$ & Weak or Slight \\
\hline$(2,3,4)$ & Moderate Importance \\
\hline$(3,4,5)$ & Moderate Plus \\
\hline$(4,5,6)$ & Strong Importance \\
\hline$(5,6,7)$ & Strong Plus \\
\hline$(6,7,8)$ & Very Strong \\
\hline$(7,8,9)$ & Very, very Strong \\
\hline$(8,9,9)$ & Extreme Importance \\
\hline
\end{tabular}

\section{MCDM METHODS FOR PERSONNEL SELECTION}

Step 1: If $X=\left\{x_{1}, x_{2}, \ldots, x_{n}\right\}$ be an objective set and $U=\left\{u_{1}, u_{2}, \ldots, u_{m}\right\}$ be a goal set, so regarding to Chang's development analysis (Ateş, Çevik, Kahraman, Gülbay, \& Erdoğan, 2006), we can compute the development analysis of goals $(u)$, based on each objectives $(x)$.

$$
\left|\begin{array}{cccc}
M_{g 1}^{1} & M_{g 1}^{2} & \ldots & M_{g 1}^{m} \\
M_{g 2}^{1} & M_{g 2}^{2} & \ldots & M_{g 2}^{m} \\
\ldots & \ldots & \ldots & \ldots \\
M_{g n}^{1} & M_{g n}^{2} & \ldots & M_{g n}^{m}
\end{array}\right|
$$

Goals and objectives are shown in rows and columns respectively. So in this matrix, there are $\mathrm{n}$ goals and m objectives. We can also say that $M_{g 4}^{2}$ is a triangular fuzzy number in fourth goal and second objective. If we assume $M_{g i}^{j}=\left(l_{i j}, m_{i j}, u_{i j}\right)$ then development analysis of $m$ objectives will be computed as below:

$$
\sum_{j=1}^{m} M_{g i}^{j}=\left(l_{i 1}, m_{i 1}, u_{i 1}\right) \oplus\left(l_{i 2}, m_{i 2}, u_{i 2}\right) \oplus \ldots \oplus\left(l_{i m}, m_{i m}, u_{i m}\right)=
$$




$$
=\left(\sum_{j=1}^{m} l_{i j}, \sum_{j=1}^{m} m_{i j}, \sum_{j=1}^{m} u_{i j}\right)=\left(l_{i}^{\prime}, m_{i}^{\prime}, u_{i}^{\prime}\right)
$$

For calculating $\left[\sum_{i=1}^{n} \sum_{j=1}^{m} M_{g i}^{j}\right]^{-1}$ by using fuzzy operator $(\oplus)$ :

$$
\begin{aligned}
& \sum \sum M_{g i}^{j}=\sum_{i=1}^{n}\left(\sum_{j=1}^{m} l_{i j}, \sum_{j=1}^{m} m_{i j}, \sum_{j=1}^{m} u_{i j}\right)=\left(\sum_{i=1}^{n} l_{i}^{\prime}, \sum_{i=1}^{n} m_{i}^{\prime}, \sum_{i=1}^{n} u_{i}^{\prime}\right) \\
& \left(\sum_{i=1}^{n} \sum_{j=1}^{m} M_{g i}^{j}\right)^{-1}=\left(\frac{1}{\sum_{i=1}^{n} u_{i}^{\prime}}, \frac{1}{\sum_{i=1}^{n} m_{i}^{\prime}}, \frac{1}{\sum_{i=1}^{n} l_{i}^{\prime}}\right)
\end{aligned}
$$

Therefore, If $M_{g i}^{1}, M_{g i}^{2}, M_{g i}^{m}$ is the amount of development analysis for $\mathrm{i}_{\mathrm{th}}$ goal, we will compute $S_{i}$ as follow:

$$
\begin{aligned}
& S_{i}=\sum_{j=1}^{m} M_{g i}^{j} \otimes\left(\sum_{i=1}^{n} \sum_{j=1}^{m} M_{g i}^{j}\right)^{-1}= \\
& =\left(l_{i}^{\prime}, m_{i}^{\prime}, u_{i}^{\prime}\right) \otimes\left(\frac{1}{\sum_{i=1}^{n} u_{i}^{\prime}}, \frac{1}{\sum_{i=1}^{n} m_{i}}, \frac{1}{\sum_{i=1}^{n} l_{i}^{\prime}}\right)=\left(\frac{l_{i}^{\prime}}{\sum_{i=1}^{n} u_{i}^{\prime}}, \frac{m_{i}^{\prime}}{\sum_{i=1}^{n} m_{i}^{\prime}}, \frac{u_{i}^{\prime}}{\sum_{i=1}^{n} l_{i}^{\prime}}\right)=\left(l_{i}, m_{i}, u_{i}\right)
\end{aligned}
$$

As you see, $\left(l_{i}, m_{i}, u_{i}\right)$ is a weight of $\mathrm{i}_{\mathrm{th}}$ criteria with fuzzy numbers. The rest will be found in the same way. In group fuzzy AHP, the weights of each criteria for each expert should be computed in geometrical mean and the result of this step will be done in next step.

Step 2: If $S_{k}=\left(l_{k}, m_{k}, u_{k}\right)$ and $S_{i}=\left(l_{i}, m_{i}, u_{i}\right)$ then the preference of $S_{\mathrm{i}}$ and $S_{\mathrm{k}}$ (the degree of possibility of $S_{i} \geq S_{k}$ ) will be calculated as below:

$$
V\left(S_{i} \geq S_{k}\right)=S U P \geq\left(\min \left\{\alpha_{s i}(x), \alpha_{s k}(y)\right\}\right)
$$

The equation of triangle fuzzy number will be extracted as followed:

$$
V\left(S_{i} \geq S_{k}\right)=\alpha_{s i}(d)=\mid \begin{array}{ll}
1 & \text { if } \left.\left(m_{i} \geq m_{k}\right)\right) \\
\frac{l_{k}-u_{i}}{\left(m_{i}-u_{i}\right)-\left(m_{k}-l_{k}\right)} & \text { Otherwise }
\end{array}
$$

Step 3: By finding the preference of $S_{i}$ and $S_{k}$ in step 2, we should calculate the degree of possibility for a convex fuzzy number as follow:

$$
V\left(S \geq S_{1}, S_{2}, \ldots, S_{k}\right)=V\left(\left(S \geq S_{1}\right),\left(S \geq S_{2}\right), \ldots,\left(S \geq S_{k}\right)\right)
$$




$$
\begin{aligned}
& =\min \left(V\left(S \geq S_{1}\right),\left(S \geq S_{2}\right), \ldots,\left(S \geq S_{k}\right)\right) \\
& =\min V\left(S \geq S_{i}\right) \quad i=1,2, \ldots, k
\end{aligned}
$$

Assume that:

$$
d^{\prime}\left(A_{i}\right)=\min V\left(S_{i} \geq S_{k}\right)
$$

For $\mathrm{k}=1,2 \ldots \mathrm{n}, \quad k \neq i$. Then the weight vector is given by:

$$
W^{\prime}=\left(d^{\prime}\left(A_{1}\right), d^{\prime}\left(A_{2}\right), \ldots, d^{\prime}\left(A_{n}\right)\right)
$$

Step 4: By normalizing this vector, we can get:

$$
W=\left(d\left(A_{1}\right), d\left(A_{2}\right), \ldots, d\left(A_{n}\right)\right)
$$

Step 5: Construct a decision matrix $(m \times n)$ that includes $\mathrm{m}$ personnel's and $\mathrm{n}$ criteria. So calculate the normalized decision matrix for positive criteria:

$$
n_{i j}=\frac{r_{i j}}{r_{j}^{*}} \quad i=1, \ldots, m, \quad j=1, \ldots, n
$$

And for negative criteria:

$$
n_{i j}=\frac{r_{j}^{\min }}{r_{i j}} \quad i=1, \ldots, m, j=1, \ldots, n
$$

$r_{j}^{*}$ is a maximum number of $r$ in the column's $j$.
Step 6: Evaluate each alternative, $A_{i}$ by the following formula:

$$
A_{i}=\sum w_{j} \cdot x_{i j}
$$

Where $x_{i j}$ is the score of the $i$ th alternative with respect to the $j$ th criteria, $w_{j}$ is the weighted criteria which have been found from Fuzzy AHP [3].

As a result, by comparing $A_{i}(\mathrm{i}=1,2, \ldots, \mathrm{m})$, the greater one is the best personnel and will be followed by rests.

\section{CASE STUDY}

One sector of Telecommunication Company should employ just one staff. The numbers of 40 people contributed in the written exam. In the first step, five of them were accepted and only one of them was chosen as the best one by using Group Fuzzy AHP and SAW methods in the second step. The authors used the opinions of three experts who

\begin{tabular}{|c|c|c|c|c|c|c|c|}
\hline & C1 & $\mathrm{C} 2$ & C3 & C4 & C5 & C6 & C7 \\
\hline C1 & $\begin{array}{c}\text { Equal } \\
\text { Importance }\end{array}$ & $\begin{array}{c}\text { Weak or } \\
\text { Slight }\end{array}$ & $\begin{array}{l}\text { Weak or } \\
\text { Slight }\end{array}$ & $\begin{array}{l}\text { Moderate } \\
\text { Plus }\end{array}$ & $\begin{array}{c}\text { Moderate } \\
\text { Importance }\end{array}$ & $\begin{array}{l}\text { Weak or } \\
\text { Slight }\end{array}$ & $\begin{array}{l}\text { Moderate } \\
\text { Importance }\end{array}$ \\
\hline C2 & & $\begin{array}{c}\text { Equal } \\
\text { Importance }\end{array}$ & $\begin{array}{c}\text { Equal } \\
\text { Importance }\end{array}$ & $\begin{array}{l}\text { Moderate } \\
\text { Importance }\end{array}$ & $\begin{array}{c}\text { Weak or } \\
\text { Slight }\end{array}$ & $\begin{array}{c}\text { Equal } \\
\text { Importance }\end{array}$ & $\begin{array}{c}\text { Weak or } \\
\text { Slight }\end{array}$ \\
\hline C3 & & & $\begin{array}{c}\text { Equal } \\
\text { Importance }\end{array}$ & $\begin{array}{l}\text { Moderate } \\
\text { Importance }\end{array}$ & $\begin{array}{c}\text { Weak or } \\
\text { Slight }\end{array}$ & $\begin{array}{c}\text { Equal } \\
\text { Importance }\end{array}$ & $\begin{array}{c}\text { Weak or } \\
\text { Slight }\end{array}$ \\
\hline C4 & & & & $\begin{array}{c}\text { Equal } \\
\text { Importance }\end{array}$ & $\begin{array}{c}\text { Weak or } \\
\text { Slight }\end{array}$ & $\begin{array}{l}\text { Moderate } \\
\text { Importance }\end{array}$ & $\begin{array}{c}\text { Weak or } \\
\text { Slight }\end{array}$ \\
\hline C5 & & & & & $\begin{array}{c}\text { Equal } \\
\text { Importance }\end{array}$ & $\begin{array}{c}\text { Weak or } \\
\text { Slight }\end{array}$ & $\begin{array}{c}\text { Equal } \\
\text { Importance }\end{array}$ \\
\hline C6 & & & & & & $\begin{array}{c}\text { Equal } \\
\text { Importance }\end{array}$ & $\begin{array}{l}\text { Weak or } \\
\text { Slight }\end{array}$ \\
\hline C7 & & & & & & & $\begin{array}{c}\text { Equal } \\
\text { Importance }\end{array}$ \\
\hline
\end{tabular}
contributed in the interview. A linguistic variable is a variable whose values are words or sentences in a natural or artificial language. So, three experts have filled up this kind of expression to compare two criteria by nine basic linguistic terms (Table 2 of first expert), based on table 1 .

Table 2: Linguistic variable of first expert

The smallest possible value, the most promising value and the largest possible value for each expert was extracted. Each linguistic variable will be transformed to three terms, therefore the authors did them in Table 3. 

A. R. Afshari
Personnel selection using group
et al. fuzzy AHP and SAW methods

In order to make geometrical mean, the authors used each experts' viewpoint and computed fuzzy weights in Table 4 (step1).

In steps 3 and 4, in order to calculate the degree of possibility for a convex fuzzy number and finally the normalized weight vector of criteria (Table 5), the preference of $S_{i}$ and $S_{k}$ should be used (steps 2, $3,4)$.

To calculate the normalized decision matrix, it is necessary to construct a decision matrix $(5 \times 7)$ that includes $\mathrm{m}$ personnel and $\mathrm{n}$ criteria as follows (steps 5,6) that will be shown in Table 6:

Table 3: Opinion of first expert

\begin{tabular}{|c|c|c|c|c|c|c|c|}
\hline CRITERIA & C1 & C2 & C3 & C4 & C5 & C6 & C7 \\
\hline C1 & $(1,1,1)$ & $(1,2,3)$ & $(1,2,3)$ & $(3,4,5)$ & $(2,3,4)$ & $(1,2,3)$ & $(2,3,4)$ \\
\hline C2 & $(0.3,0.5,1)$ & $(1,1,1)$ & $(1,1,1)$ & $(2,3,4)$ & $(1,2,3)$ & $(1,1,1)$ & $(1,2,3)$ \\
\hline C3 & $(0.3,0.5,1)$ & $(1,1,1)$ & $(1,1,1)$ & $(2,3,4)$ & $(1,2,3)$ & $(1,1,1)$ & $(1,2,3)$ \\
\hline C4 & $(0.2,0.3,0.3)$ & $(0.3,0.3,0.5)$ & $(0.3,0.3,0.5)$ & $(1,1,1)$ & $(0.3,0.5,1)$ & $(0.3,0.3,0.5)$ & $(1,2,3)$ \\
\hline C5 & $(0.3,0.3,0.5)$ & $(0.3,0.5,1)$ & $(0.3,0.5,1)$ & $(1,2,3)$ & $(1,1,1)$ & $(0.3,0.5,1)$ & $(1,1,1)$ \\
\hline C6 & $(0.3,0.5,1)$ & $(1,1,1)$ & $(1,1,1)$ & $(2,3,4)$ & $(1,2,3)$ & $(1,1,1)$ & $(1,2,3)$ \\
\hline C7 & $(0.3,0.3,0.5)$ & $(0.3,0.5,1)$ & $(0.3,0.5,1)$ & $(0.3,0.5,1)$ & $(1,1,1)$ & $(0.3,0.5,1)$ & $(1,1,1)$ \\
\hline
\end{tabular}

Table 4: Criteria's weight with fuzzy set

\begin{tabular}{|l|l|c|}
\hline & \multicolumn{1}{|c|}{ Criteria } & Fuzzy weights \\
\hline C1 & Ability to work in different business units & $(0.129,0.255,0.483)$ \\
\hline C2 & Past experience & $(0.095,0.179,0.341)$ \\
\hline C3 & Team player & $(0.089,0.169,0.308)$ \\
\hline C4 & Fluency in a foreign language & $(0.040,0.075,0.150)$ \\
\hline C5 & Strategic thinking & $(0.052,0.091,0.196)$ \\
\hline C6 & Oral communication skills & $(0.086,0.165,0.287)$ \\
\hline C7 & Computer skills & $(0.036,0.064,0.122)$ \\
\hline
\end{tabular}

Table 5: Weights of criteria

\begin{tabular}{|l|l|c|}
\hline & \multicolumn{1}{|c|}{ Criteria } & Weights \\
\hline C1 & Ability to work in different business units & 0.290 \\
\hline C2 & Past experience & 0.213 \\
\hline C3 & Team player & 0.196 \\
\hline C4 & Fluency in a foreign language & 0.030 \\
\hline C5 & Strategic thinking & 0.084 \\
\hline C6 & Oral communication skills & 0.184 \\
\hline C7 & Computer skills & 0.003 \\
\hline
\end{tabular}

Table 6: Normalized decision matrix with alternatives' weights

\begin{tabular}{|c|c|c|c|c|c|c|c|}
\hline Weights & 0.290 & 0.213 & 0.196 & 0.030 & 0.084 & 0.184 & 0.003 \\
\hline & C1 & C2 & C3 & C4 & C5 & C6 & C7 \\
\hline P1 & 3.915 & 6.649 & 3.634 & 2.621 & 2.000 & 2.289 & 2.000 \\
\hline P2 & 4.000 & 3.634 & 5.313 & 3.302 & 4.309 & 2.621 & 6.952 \\
\hline P3 & 6.952 & 5.646 & 4.309 & 2.289 & 4.642 & 4.932 & 2.621 \\
\hline p4 & 3.634 & 2.520 & 4.932 & 2.621 & 2.621 & 2.000 & 4.932 \\
\hline P5 & 4.309 & 2.520 & 3.175 & 4.121 & 4.481 & 2.621 & 4.932 \\
\hline
\end{tabular}

As a result, the rank of alternatives will be shown in Table 7. (Step 6)

Finally, Table 7 shows that personnel 3 is the best for the considered job and it will be followed by P2, P1, P5 and P4 respectively.
Table 7: Personnel rank

\begin{tabular}{|c|c|}
\hline Personnel & Ranked \\
\hline P3 & 1 \\
\hline P2 & 2 \\
\hline P1 & 3 \\
\hline P5 & 4 \\
\hline P4 & 5 \\
\hline
\end{tabular}




\section{CONCLUSION}

Decision-makers face vagueness in the decision making process. In many cases, group decision making can improve the consistency of the human decision making process and using fuzzy numbers helps to reach a more effective decision. In this paper, personnel evaluation process is modeled by using the FAHP based on Chang's Algorithm. In order to validate the practicality of the proposed model, it is applied to a personnel selection problem in a Telecommunication company. There are many other multi-attribute evaluation methods that can be combined with fuzzy logics such as TOPSIS and ELECTRE as presented in the literature. The application of these methods to personnel evaluation problem with more evaluation criteria might be suggested for further research.

\section{REFERENCES}

Afshari, A. R., Yusuff, R. M., \& Derayatifar, A. R. (2013). Linguistic extension of fuzzy integral for group personnel selection problem. Arabian Journal for Science and Engineering, 38(10), 2901-2910.

Alliger, G. M., Feinzig, S. L., \& Janak, E. A. (1993). Fuzzy sets and personnel selection: Discussion and an application. Journal of Occupational and Organizational Psychology, 66, 163-169.

Ateş, N. Y., Çevik, S., Kahraman, C., Gülbay, M., \& Erdoğan, S. A. (2006). Multi attribute performance evaluation using a hierarchical fuzzy TOPSIS method. Fuzzy Applications in Industrial Engineering (pp. 537-572): Springer.

Baležentis, A., Baležentis, T., \& Brauers, W. K. (2012). Personnel selection based on computing with words and fuzzy MULTIMOORA. Expert Systems with applications, 39(9), 7961-7967.

Ballı, S., \& Korukoğlu, S. (2014). Development of a fuzzy decision support framework for complex multi-attribute decision problems: A case study for the selection of skilful basketball players. Expert Systems, 31(1), 56-69

Boran, F. E., Genç, S., \& Akay, D. (2011). Personnel selection based on intuitionistic fuzzy sets. Human Factors and Ergonomics in Manufacturing \& Service Industries, 21(5), 493-503.

Butkiewicz, B. S. (2002, October). Selection of staff for enterprise using fuzzy logic. In Systems, Man and Cybernetics, 2002 IEEE International Conference on (Vol. 4). IEEE.

Capaldo, G., \& Zollo, G. (2001). Applying fuzzy logic to personnel assessment: A case study. Omega, 29(6), 585-597.

Chen, L. S., \& Cheng, C. H. (2005). Selecting IS personnel use fuzzy GDSS based on metric distance method. European Journal of Operational Research, 160(3), 803-820.

Dadelo, S., Turskis, Z., Zavadskas, E. K., \& Dadeliene, R. (2012). Multiple criteria assessment of elite security personal on the basis of aras and expert methods. Economic Computation and Economic Cybernetics Studies and Research, 46(4), 65-87.

Dadelo, S., Turskis, Z., Zavadskas, E. K., \& Dadeliene, R. (2013). Integrated multi-criteria decision making model based on wisdom-of-crowds principle for selection of the group of elite security guards. Archives of Budo, 1(9), 135-147.

Dağdeviren, M. (2010). A hybrid multi-criteria decision-making model for personnel selection in manufacturing systems. Journal of Intelligent manufacturing, 21(4), 451-460.

Dursun, M., \& Karsak, E. E. (2010). A fuzzy MCDM approach for personnel selection. Expert Systems with Applications, 37(6), 4324-4330.

El-Santawy, M. F., \& El-Dean, R. A. Z. (2012). On using VIKOR for ranking personnel problem. Life Science Journal, 9(4), 1534-1536.

Golec, A., \& Kahya, E. (2007). A fuzzy model for competency-based employee evaluation and selection. Computers and Industrial Engineering, 52(1), 143-161.

Hadad, Y., Keren, B., \& Laslo, Z. (2013). A decisionmaking support system module for project manager selection according to past performance.

International Journal of Project Management, 31(4), 532-541.

Kabak, M. (2013). A Fuzzy DEMATEL-ANP Based Multi Criteria Decision Making Approach For Personnel Selection. Journal of Multiple-Valued Logic \& Soft Computing, 20(5/6), 571-593.

Kabak, M., Burmaoğlu, S., \& Kazançoğlu, Y. (2012). A fuzzy hybrid MCDM approach for professional selection. Expert Systems with Applications, 39(3), 3516-3525.

Kahraman, C., Cebeci, U., \& Ulukan, Z. (2003). Multicriteria supplier selection using fuzzy AHP. Logistics information management, 16(6), 382-394.

Kelemenis, A., \& Askounis, D. (2010). A new TOPSISbased multi-criteria approach to personnel selection. [doi: 10.1016/j.eswa.2009.12.013]. Expert Systems with Applications, 37(7), 4999-5008.

Keršuliene, V., \& Turskis, Z. (2011). Integrated fuzzy multiple criteria decision making model for architect selection. Technological and Economic Development of Economy, 17(4), 645-666.

Keršulienė, V., \& Turskis, Z. (2014). A hybrid linguistic fuzzy multiple criteria group selection of a chief accounting officer. Journal of Business Economics and Management, 15(2), 232-252.

Liang, G. S., \& Wang, M. J. J. (1992). Personnel placement in a fuzzy environment. Computers and Operations Research, 19(2), 107-121.

Liang, G. S., \& Wang, M. J. J. (1994). Personnel selection using fuzzy MCDM algorithm. European Journal of Operational Research, 78(1), 22-33. 
Liao, S. K., \& Chang, K. L. (2009a). Select televised sportscasters for Olympic games by analytic network process. Management Decision, 47(1), 1423.

Liao, S. K., \& Chang, K. L. (2009b). Selecting public relations personnel of hospitals by analytic network process. Journal of Hospital Marketing and Public Relations, 19(1), 52-63.

Lin, H. T. (2010). Personnel selection using analytic network process and fuzzy data envelopment analysis approaches. Computers and Industrial Engineering, 59(4), 937-944.

Lovrich, M. (2000). A fuzzy approach to personnel selection. Cybernetics and Systems 2000: Proceedings of the Fifteenth European Meeting on Cybernetics and Systems Research (pp. 234-239).

Md Saad, R., Ahmad, M. Z., Abu, M. S., \& Jusoh, M. S. (2014). Hamming distance method with subjective and objective weights for personnel selection. The Scientific World Journal, 2014.

Rouyendegh, B. D., \& Erkan, T. E. (2013). An application of the fuzzy electre method for academic staff selection. Human Factors and Ergonomics in Manufacturing \& Service Industries, 23(2), 107-115.

Rouyendegh, B. D., \& Erkart, T. (2012). Selection of academic staff using the fuzzy analytic hierarchy process (FAHP): A pilot study. Tehnicki Vjesnik, 19(4), 923-929.

Saaty, T. L. (1980). The Analytic Hierarchy Process. New York: McGraw-Hill.
Vaidya, O. S., \& Kumar, S. (2006). Analytic hierarchy process: An overview of applications. European Journal of Operational Research, 169(1), 1-29.

Yaakob, S. B., \& Kawata, S. (1999). Workers' placement in an industrial environment. Fuzzy Sets and Systems, 106(3), 289-297.

Yu, D., Zhang, W., \& Xu, Y. (2013). Group decision making under hesitant fuzzy environment with application to personnel evaluation. KnowledgeBased Systems, 52, 1-10.

Zadeh, L. A. (1965). Fuzzy sets. Information and Control, 8(3), 338-353.

Zadeh, L. A. (1975). The concept of a linguistic variable and its application to approximate reasoning-I. Information Sciences, 8(3), 199-249.

Zavadskas, E. K., Turskis, Z., Tamošaitiene, J., \& Marina, V. (2008). Multicriteria selection of project managers by applying grey criteria. Technological and Economic Development of Economy, 14(4), 462-477.

Zhang, S.-F., \& Liu, S.-Y. (2011). A GRA-based intuitionistic fuzzy multi-criteria group decision making method for personnel selection. Expert Systems with Applications, 38(9), 11401-11405.

Zolfani, S. H., Rezaeiniya, N., Aghdaie, M. H., \& Zavadskas, E. K. (2012). Quality control manager selection based on AHP-COPRAS-G methods: a case in Iran. Economic Research-Ekonomska Istraživanja, 25(1), 72-86.

\title{
SELEKCIJA KADROVA UPOTREBOM GRUPNE FAZI AHP I SAW METODE
}

\begin{abstract}
Evaluacija i selekcija kadrova predstavlja veoma važnu aktivnost preduzeća. Različiti poslovi zahtevaju razlicite sposobnosti i kreiranje kriterijuma koji mogu da izmere te sposobnosti. Potreban je pogodan i fleksibilan metod koji bi vrednovao učinak svakog kandidata u skladu sa zahtevima odredjenog posla. Analitički hijerarhijski process (AHP) predstavlja jednu od multikriterijumskih metoda donosenja odluka, metoda koja izvodi skalu odnosa iz uparenih poredjenja. Simple Additive Weighting je prosta i najčešće korišćena multiatributivna tehnika donošenja odluka. Ova metoda se zasniva na prosečnim težinama. Metoda koja je opisana u ovom radu uspešno modeluje dvosmislenost i nepreciznost koje se odnose na process poredjenja $i$ smanjuje ličnu pristrasnost. Rad daje analizu Analitičkog hijerarhijskog procesa da bi proces regrutovanja, zasnovan na fazi višestrukom kriterijumu za donošenje odluka bio racionalniji kako bi se postigao cilj u selekciji kadrova. Najzad, prikazan je jedan primer kojim se demonstrira upotrebljivost predložene metode.
\end{abstract}

Ključne reči: Fazi AHP, SAW metoda, Selekcija kadrova, Fazi donošenje odluka. 